\title{
THE TECHNIQUE FOR ORDER OF PREFERENCE BY SIMILARITY TO IDEAL SOLUTION (TOPSIS) UNTUK PENENTUAN PENERIMA BEASISWA
}

\author{
Sandi Fajar Rodiyansyah, \\ Fakultas Teknik, Universitas Majalengka \\ galuh29@gmail.com
}

\begin{abstract}
ABSTRAKSI
TOPSIS menggunakan prinsip bahwa alternatif yang terpilih harus mempunyai jarak terdekat dari solusi ideal positif dan jarak terpanjang (terjauh) dari solusi ideal negatif dari sudut pandang geometris dengan menggunakan jarak euclidean (jarak antara dua titik) untuk menentukan kedekatan relatif dari suatu alternatif dengan solusi optimal. Pada makalah ini dijelaskan tentang menggunakan TOPSIS untuk menentukan penerima beasiswa.
\end{abstract}

Kata kunci : TOPSIS, alternatif, solusi ideal, jarak euclidean.

\section{PENDAHULUAN}

Pendidikan adalah usaha sadar dan terencana untuk mewujudkan suasana belajar dan proses pembelajaran agar peserta didik secara aktif mengembangkan potensi dirinya untuk memiliki kekuatan spiritual keagamaan, pengendalian diri, kepribadian, kecerdasan, akhlak mulia, serta keterampilan yang diperlukan dirinya dan masyarakat.

Salah satu jenjang pendidikan yang menetukan kualitas sumber daya manusia adalah pendidikan tinggi. Pada jenjang ini, peserta didik disiapkan untuk memasuki dunia kerja sesuai dengan program studi yang diikutinya. Pada jenjang pendidikan ini, biasanya masyarakat umum memandang bahwa jenjang pendidikan ini memerlukan biaya yang tidak sedikit.

Berdasarkan hal diatas, salah satu program yang diselenggarakan oleh pemerintah ataupun institusi pendidikan adalah program penyaluran beasiswa yang bertujuan untuk membantu peserta didik khususnya dalam hal biaya perkuliahan. Secara umum, penyaluran beasiswa dapat dibagi menjadi dua jenis. Pertama, beasiswa prestasi, adalah beasiswa yang diberikan kepada peserta didik yang memiliki prestasi diatas rata-rata tanpa memperhatikan keadaan ekonomi peserta didik tersebut. Sedangkan yang kedua adalah beasiswa kurang mampu, adalah beasiswa yang diberikan kepada peserta didik yang secara ekonomi dinilai tidak mampu dan berhak menerima beasiswa ini sebagai bantuan dana pendidikan peserta didik tersebut.

Selama ini, dalam hal seleksi beasiswa untuk menentukan siapa yang berhak menerima beasiswa biasanya institusi pendidikan hanya menggunakan teknik statistik biasa yang memungkinkan terjadi kekeliruan dalam hal pengambilan keputusannya. Atas dasar itulah, diperlukan suatu teknik untuk melakukan proses seleksi mahasiswa yang dianggap layak menerima beasiswa. Pada makalah ini dibahas salah satu teknik penentuan keputusan dengan menggunakan The Technique for Order of Preference by Similarity to Ideal Solution beserta penerapannya pada kasus.

\section{DASAR TEORI}

Sistem Pendukung Keputusan (SPK) / Decision Support System (DSS) secara umum didefinisikan sebagai sebuah sistem yang mampu memberikan kemampuan pemecahan masalah maupun kemampuan pengkomunikasian untuk masalah dengan kondisi semi terstruktur dan tak terstruktur. Sistem ini digunakan untuk membantu pengambilan keputusan dalam situasi semi terstruktur dan situasi yang tidak terstruktur, dimana tak seorangpun tahu secara pasti bagaimana keputusan seharusnya dibuat [1].Tujuan dari SPK adalah memeberikan informasi kepada pengguna untuk proses pengambilan keputusan yang lebih efektif. 
The Technique for Order of Preference by Similarity to Ideal Solution (TOPSIS) adalah salah satu metode pengambilan keputusan multikriteria yang pertama kali diperkenalkan oleh Yoon dan Hwan [2]. TOPSIS menggunakan prinsip bahwa alternatif yang terpilih harus mempunyai jarak terdekat dari solusi ideal positif dan jarak terpanjang (terjauh) dari solusi ideal negatif dari sudut pandang geometris dengan menggunakan jarak Euclidean (jarak antara dua titik) untuk menentukan kedekatan relatif dari suatu alternatif dengan solusi optimal.

Solusi ideal positif didefinisikan sebagai jumlah dari seluruh nilai terbaik yang dapat dicapai untuk setiap atribut, sedangkan solusi negatif-ideal terdiri dari seluruh nilai terburuk yang dicapai untuk setiap atribut. TOPSIS mempertimbangkan keduanya, jarak terhadap solusi ideal positif dan jarak terhadap solusi ideal negatif dengan mengambil kedekatan relatif terhadap solusi ideal positif.

Berdasarkan perbandingan terhadap jarak relatifnya, susunan prioritas alternatif bisa dicapai. Metode ini banyak digunakan untuk menyelesaikan pengambilan keputusan secara praktis. Hal ini disebabkan konsepnya sederhana dan mudah dipahami, komputasinya efisien, dan memiliki kemampuan mengukur kinerja relatif dari alternatif-alternatif keputusan. [3] Adapun langkah-langkah algoritma TOPSIS adalah sebagai berikut :

1. Menentukan rangking setiap alternatif

TOPSIS membutuhkan ranking kinerja setiap alternatif Ai pada setiap kriteria $\mathrm{Cj}$ yang ternormalisasi yaitu:

$$
r_{i j}=\frac{x_{i j}}{\sqrt{\sum_{i=1}^{m} x_{i j}^{2}}}
$$

Dengan $i=1,2, \ldots \mathrm{m}$ dan $\mathrm{j}=1,2, \ldots \mathrm{n}$.

2. Membuat matrik keputusan ternormalisasi terbobot

$$
y_{i j}=w_{i} r_{i j}
$$

Dengan $\mathrm{i}=1,2, \ldots \mathrm{m}$ dan $\mathrm{j}=1,2, \ldots \mathrm{n}$.

3. Menentukan solusi ideal positif dan negatif Solusi ideal positif A+ dan solusi ideal negatif A- dapat ditentukan berdasarkan ranking bobot ternormalisasi $\left(y_{i j}\right)$ sebagai berikut :

$$
\begin{aligned}
& A^{+}=\left(y_{1}^{+}, y_{2}^{+}, y_{3}^{+}, \ldots, y_{n}^{+}\right) \\
& A^{-}=\left(y_{1}^{-}, y_{2}^{-}, y_{3}^{-}, \ldots, y_{n}^{-}\right)
\end{aligned}
$$

$y_{1}^{+}: \quad-\max y_{i j}$, jika $\mathrm{j}$ adalah atribut keuntungan (benefit)

- $\min y_{i j}$, jika $\mathrm{j}$ adalah atribut biaya (cost)

$y_{1}^{-}: \quad-\quad \min y_{i j}$, jika $\mathrm{j}$ adalah atribut keuntungan (benefit)

- $\quad \max y_{i j}$, jika $\mathrm{j}$ adalah atribut biaya (cost)

4. Menghitung jarak dengan solusi ideal Jarak alternatif $A_{i}$ dengan solusi ideal positif dihitung dengan menggunakan rumus

$$
D_{i}^{+}=\sqrt{\sum_{j=1}^{n}\left(y_{1}^{+}-y_{i j}\right)^{2}} ; i
$$

Jarak alternatif $A_{i}$ dengan solusi ideal positif dihitung dengan menggunakan rumus

$$
\begin{array}{r}
D_{i}^{-}=\sqrt{\sum_{j=1}^{n}\left(y_{i j}-y_{1}^{-}\right)^{2}} ; i \\
=1,2, \ldots, m
\end{array}
$$

5. Menentukan nilai preferensi untuk setiap alternatif

Nilai preferensi untuk setiap alternatif $\left(V_{i}\right)$ diberikan sebagai :

$$
V_{i}=\frac{D_{i}^{-}}{D_{i}^{-}+D_{i}^{+}}
$$

\section{PEMBAHASAN}

Pada bagian ini, akan dijelaskan proses pengolahan data untuk menetukan mahasiswa yang berhak menerima beasiswa. Adapun kriteria yang digunakan dalam penentuan penerima beasiswa tertuang pada Tabel 1 .

Tabel 1 : Nilai Bobot

\begin{tabular}{lc}
\hline \multicolumn{1}{c}{ Kriteria } & Bobot \\
\hline IPK (A) & 80 \\
Wawancara (B) & 75 \\
Karya Ilmiah (C) & 90 \\
Penghasilan Orang Tua (D) & 40 \\
\hline
\end{tabular}

Langkah pertama yang dilakukan adalah membuat matrik keputusan. Pada makalah ini digunakan 5 orang mahasiswa yang digunakan sebagai sample. Data matrik keputusan dapat terlihat pada tabel 2 . 
Tabel 2 : Nilai untuk Setiap Alternatif

\begin{tabular}{cccccc}
\hline \multirow{2}{*}{ No } & \multirow{2}{*}{ Alt } & \multicolumn{4}{c}{ Kriteria } \\
\cline { 3 - 6 } & & A & B & C & D \\
\hline 1 & A & 77 & 64 & 81 & 58 \\
2 & B & 77 & 77 & 73 & 88 \\
3 & C & 53 & 73 & 55 & 70 \\
4 & D & 77 & 67 & 74 & 56 \\
5 & E & 63 & 80 & 85 & 84 \\
\hline
\end{tabular}

Langkah berikutnya adalah menentukan rangking setiap alternatif dengan menggunakan persamaan (1). Hasil perhitungan rangking setiap alternatif tertuang pada tabel 3 .

Tabel 3 : Nilai Ranking untuk Setiap Alternatif

\begin{tabular}{cccccc}
\hline \multirow{2}{*}{ No } & \multirow{2}{*}{ Alt } & \multicolumn{4}{c}{ Kriteria } \\
\cline { 3 - 6 } & & $\mathbf{A}$ & $\mathbf{B}$ & $\mathbf{C}$ & $\mathbf{D}$ \\
\hline 1 & A & 0,4913 & 0,3951 & 0,4874 & 0,3583 \\
2 & B & 0,4913 & 0,4753 & 0,4393 & 0,5437 \\
3 & C & 0,3382 & 0,4506 & 0,3310 & 0,4325 \\
4 & D & 0,4913 & 0,4136 & 0,4453 & 0,3460 \\
5 & E & 0,4020 & 0,4938 & 0,5115 & 0,5190 \\
\hline
\end{tabular}

Selanjutnya adalah membuat matrik keputusan ternormalisasi terbobot. Perhitungan ini menggunakan persamaan (2). Adapun hasil perhitungan ini dapat dilihat pada tabel 4 .

Tabel 4 : Matrik Keputusan Ternormalisasi Terbobot

\begin{tabular}{cccccc}
\hline \multirow{2}{*}{ No } & \multirow{2}{*}{ Alt } & \multicolumn{4}{c}{ Kriteria } \\
\cline { 3 - 6 } & & A & B & C & D \\
\hline $\mathbf{1}$ & A & 39,3027 & 29,6302 & 43,8679 & 4,3330 \\
$\mathbf{2}$ & B & 39,3027 & 35,6488 & 39,5353 & 1,7466 \\
$\mathbf{3}$ & C & 27,0525 & 33,7969 & 29,7869 & 7,2985 \\
$\mathbf{4}$ & D & 39,3027 & 31,0191 & 40,0769 & 3,8388 \\
$\mathbf{5}$ & E & 32,1568 & 37,0377 & 46,0342 & 0,7581 \\
\hline \multicolumn{4}{c}{ Setah }
\end{tabular}

Setelah matrik keputusan ternormalisasi tebobot terbentuk, langkah berikutnya adalah menentukan solusi ideal positif dan negatif. Penentuan ini didasarkan pada kriteria yang dibuat sebelumnya. Apabila kriteria tersebut mendukung (benetif) atau menguntungkan decision maker maka digunakan hasil perhitungan solusi ideal positif pada persamaan (3.a), sedangkan apabila kriteria itu sebagai kriteria biaya (cost) maka digunakan hasil perhitungan solusi ideal negatif pada persamaan (3.b).

Dalam hal ini, penulis berasumsi semakin kecil penghasilan orang tua maka akan semakin menguntungkan alternatif tersebut untuk di prioritaskan. Oleh karena itu, maka kriteria penghasilan orang tua (D) akan menggunakan perhitungan solusi ideal negatif. Adapun hasil perhitungan solusi ideal positif dan negatif tertuang pada tabel 5 .

Tabel 5 : Solusi Ideal Positif dan Negatif

\begin{tabular}{ccccc}
\hline Solusi & \multicolumn{4}{c}{ Kriteria } \\
\cline { 2 - 5 } Ideal & $\mathbf{A}$ & $\mathbf{B}$ & $\mathbf{C}$ & $\mathbf{D}$ \\
\hline Positif & 39,3027 & 37,0377 & 46,0342 & 13,8388 \\
Negatif & 27,0525 & 29,6302 & 29,7869 & 21,7466 \\
\hline
\end{tabular}

Setelah menghasilkan solusi ideal positif dan negatif, langkah berikutnya adalah menentukan jarak setiap alternatif dengan solusi ideal untuk solusi ideal positif menggunakan persamaan (4) dan solusi ideal negatif dengan menggunakan persamaan (5). Hasil perhitungan dapat dilihat pada tabel 6

Tabel 6 : Jarak Setiap Alternatif Terhadap Solusi Ideal

\begin{tabular}{ccc}
\hline .Alternatif & $\begin{array}{c}\text { Solusi Ideal } \\
\text { Positif }\end{array}$ & $\begin{array}{c}\text { Solusi Ideal } \\
\text { Negatif }\end{array}$ \\
\hline A & 7,7336 & 20,08246 \\
B & 10,3296 & 16,77269 \\
C & 20,8930 & 6,094919 \\
D & 8,4684 & 17,90014 \\
E & 9,9470 & 18,59784 \\
\hline
\end{tabular}

Langkah terakhir adalah menentukan nilai preferensi untuk setiap alternatif dengan menggunakan persamaan (6). Hasil dari perhitungan ini, kemudian di urutkan (sorting) secara descending dan terkahir tinggal diambil $\mathrm{n}$ alternatif terbesar yang dinyatakan lolos seleksi. Adapun hasil perhitungan ini dapat dilihat pada tabel 7 .

Tabel 7 : Nilai Preferensi Setiap Alternatif

\begin{tabular}{cc}
\hline Alternatif & Preferensi \\
\hline A & 0,721972913 \\
B & 0,618866992 \\
C & 0,2258389 \\
D & 0,678843844 \\
E & 0,651531186 \\
\hline
\end{tabular}

Setelah diurutkan, maka hasil dari perhitungan ini tertuang pada tabel 8 .

Tabel 8 : Pengurutan Nilai Preferensi Untuk Setiap Alternatif

\begin{tabular}{cc}
\hline Alternatif & Preferensi \\
\hline A & 0,721973 \\
D & 0,678844 \\
\hline
\end{tabular}




\begin{tabular}{cc}
\hline Alternatif & Preferensi \\
\hline E & 0,651531 \\
B & 0,618867 \\
C & 0,225839 \\
\hline
\end{tabular}

Dari tabel tersebut terlihat nilai preferensi terbesar diperoleh alternatif $\mathrm{A}$ dan nilai preferensi terkecil diperoleh alternatif $\mathrm{C}$. Dengan demikian, apabila pengambil keputusan akan mengambil tiga dari lima alternatif, maka yang lolos mendapatkan beasiswa pada kasus ini adalah alternatif A, D dan E.

Penulis mencoba membuktikan hasil perhitungan manual diatas dengan hasil perhitungan prototype program yang penulis kembangkan dengan menggunakan bahasa pemrograman Java dengan data yang sama. Adapun hasil dari perhitungan dengan prototype program diperoleh hasil yang terlihat pada gambar 1.

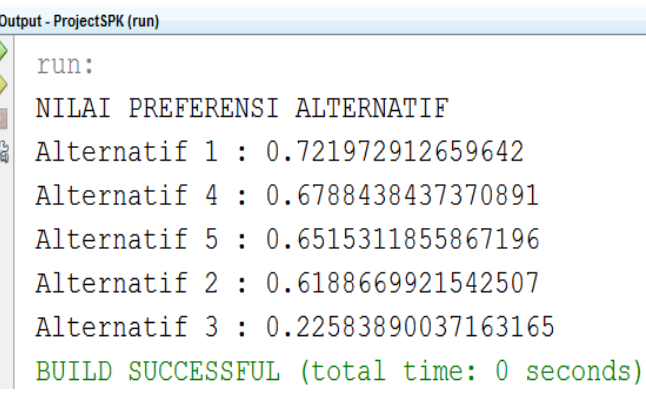

Gambar 1 : Hasil Running Program

\section{KESIMPULAN}

Sebagai suatu usaha untuk mendapatkan solusi terbaik atas permasalahan multiple criteria decision making dapat digunakan Technique for Order Performance by Similarity to Ideal Solution, yang dalam implementasinya akan memunculkan beberapa alternatif solusi berdasarkan hasil ranking kumulatif, yang kemudian dapat dipilih satu solusi tertentu, berdasarkan kriteria tambahan dari pemegang kebijakan (pimpinan).

Telah diimplementasikan The Technique for Order of Preference by Similarity to Ideal Solution (TOPSIS) dengan menggunakan bahasa Java dengan studi kasus seleksi penerima beasiswa.

\section{DAFTAR PUSTAKA}

[1] Turban, Efrain dan Aronson, Jay , 2001,Decision Suport System and Intelligent System, Prentice Hall, New Jersey.

[2] Hwang, C.L. dan Yoon, K. 1995. Multiple Attribute Decision Making: An Introduction. Sage Publications, Thousand Oaks: London.

[3] Kusumadewi, S., Hartati, S., Harjoko, A., dan Wardoyo, R. (2006). Fuzzy MultiAtribute Decision Making (FUZZY MADM). Yogyakarta: Graha Ilmu. 